\title{
Complex verbs, simple alternations: valency and verb classes in Jaminjung.
}

\author{
Document Version \\ Other version
}

Link to publication record in Manchester Research Explorer

\section{Citation for published version (APA):}

Schultze-Berndt, E. (2015). Complex verbs, simple alternations: valency and verb classes in Jaminjung. In A. Malchukov, \& B. Comrie (Eds.), Valency Classes in the World's Languages: Case Studies from Austronesia, the Pacific, the Americas, and Theoretical Outlook (Vol. 2, pp. 1117-1162). (Comparative Handbooks of Linguistics; No. 2). de Gruyter, Walter GmbH \& Co.

\section{Published in:}

Valency Classes in the World's Languages:

\section{Citing this paper}

Please note that where the full-text provided on Manchester Research Explorer is the Author Accepted Manuscript or Proof version this may differ from the final Published version. If citing, it is advised that you check and use the publisher's definitive version.

\section{General rights}

Copyright and moral rights for the publications made accessible in the Research Explorer are retained by the authors and/or other copyright owners and it is a condition of accessing publications that users recognise and abide by the legal requirements associated with these rights.

\section{Takedown policy}

If you believe that this document breaches copyright please refer to the University of Manchester's Takedown Procedures [http://man.ac.uk/04Y6Bo] or contact uml.scholarlycommunications@manchester.ac.uk providing relevant details, so we can investigate your claim.

\section{OPEN ACCESS}




\title{
Complex verbs, simple alternations: valency and verb classes in Jaminjung
}

\author{
Eva Schultze-Berndt, University of Manchester
}

To appear in: B. Comrie and A. Malchukov (eds.), Valency Classes: A comparative handbook. Berlin: Mouton de Gruyter. (Publication expected 2012)

\section{Introduction}

This chapter investigates valency patterns in Jaminjung, a name used here for two named varieties, Jaminjung and Ngaliwurru, which are mutually intelligible and exhibit mainly lexical differences. They belong to the small Jaminjungan (or Western Mirndi) subgroup of the geographically discontinuous Mirndi family (Chadwick 1997; Harvey 2008), one of the nonPama-Nyungan families of northern Australia. The traditional country of Jaminjung and Ngaliwurru speakers is located north and south of the Victoria River around the present-day township of Timber Creek in the Northern Territory. Jaminjung is no longer acquired by children; only a few dozen elderly speakers are alive today. The discussion in this chapter is based on both elicited and naturalistic speech recorded during multiple field trips undertaken by the author between 1993 and 2008. All examples were offered by speakers either unprompted or prompted by translation equivalents or visual stimuli; no examples were merely constructed by the linguist and submitted to grammaticality judgments.

\section{Basics of morphosyntax of Jaminjung}

Jaminjung shares many of its main characteristics with other Australian languages, in particular other non-Pama-Nyungan languages (for a brief overview, see Gaby 2008). It has "free word order" in the sense that word order is not used to distinguish the grammatical roles of arguments, but is rather conditioned by information structure on a discourse pragmatic level. It is a double-marking language in the sense of Nichols (1986), i.e. the role of core arguments is indicated both by bound pronominals on verbs and by case marking on noun phrases (see further Section 3.1). Noun phrases can be freely 
omitted if understood from context (zero anaphora). There is no clearcut distinction between nouns and adjectives, in that property expressions can function as heads of noun phrases in their own right.

For case-marked noun phrases, alignment follows an ergative-absolutive pattern, with optional ergativity, but no clearcut split (see Section 4.1). As in many other Australian languages, the instrumental case is identical to the ergative; both can be subsumed under the general role of 'effector' (Van Valin \& Wilkins 1996). Other case markers include the dative, locative, allative, ablative, and origin case, and a number of possessive markers found on adnominal modifiers and on nominal predicates. Case may be marked on one (as in (1)) or more elements of a noun phrase.

$\begin{array}{lll}\text { Gurrany } & \text { ya-wun-dum } & \text { [ngarrgina-bina yagbali]! } \\ \text { NEG } & \text { IRR-2DU.S-come } & \text { 1SG:POSS-ALL }\end{array}$

'Don't come here to my place, you two!'

The fact that case only has to be marked once can be used as evidence for a configurational rather than flat structure, i.e. the phrasal status of noun phrases. If the syntactic structure were completely flat, the grammatical function of each individual nominal would have to be flagged, that is, one would expect consistent case marking on each and every one of the nominal constituents. And while the word order within a noun phrase is relatively free, there are certain restrictions which likewise suggest a phrasal rather than flat status. Discontinuous noun phrases are attested, but are relatively rare (approximately $8 \%$ of all multi-word NPs), and restricted to very specific information structure configurations such as contrastive focus with "given" entity nomina (for details, see Schultze-Berndt 2000: Ch. 2; Schultze-Berndt \& Simard to appear).

Simple clauses can be divided into nonverbal and verbal clauses. The predicate in nonverbal clauses - with the subtypes of equative, ascriptive and possessive clauses - can be an absolutive noun phrase $^{1}$ or a possessive noun phrase marked with dative case or one of the possessive suffixes. Clauses with locative predicate always contain a locative verb gagba 'be' and thus do not fall under the nonverbal type. A peculiarity of ascriptive clauses is crossreferencing of the absolutive subject (predication base) with an oblique (dative) enclitic pronominal for speech act participants; compare the nonverbal clauses in (2) ( $3^{\text {rd }}$ person) and (3) (2nd person).

1 Since the absolutive is formally unmarked, it is not glossed in examples. 
Majani yinthu jarlag maybe PROX good

'Maybe this one is good.'

$\begin{array}{ll}\text { (3) Jamang } & \text { gujugu=ngunggu nami! } \\ \text { ENOUGH } & \text { big=2SG.DAT 2SG }\end{array}$

'You are big enough (to fight for yourself)!'

A pervasive feature of Jaminjung lexicon and grammar, which proves to be highly relevant for the discussion of verb classes and alternations, is a division of the "verbal" lexicon into two distinct parts of speech. This is an areal phenomenon found in a number of unrelated languages in Northern Australia (for overview discussions see e.g. Capell 1979; Dixon 2001; McGregor 2002; Schultze-Berndt 2003). Inflecting verbs (IVs), i.e. those taking obligatory pronominal prefixes and tense and mood marking, form a closed class with only about 30 members (with some variation depending on the dialect affiliation and also the age of individual speakers). The morphological structure of IVs is shown in (4). ${ }^{2}$

$$
\text { (IMP/IRR-)A-(POT-)P-Verb_root(-RFL/REC)(-TAM) }
$$

The predicate of an independent verbal clause may be an IV on its own, i.e. as a simple predicate, or a complex predicate. In complex predicates, IVs combine with members of a distinct part of speech, variously labelled "coverb", "preverb", "verbal particle", and "uninflecting verb" (UV) in the literature. UVs can be distinguished from IVs by the fact that they cannot take verbal inflections, and from nominals in that they do not co-occur with determiners such as demonstratives, and only take a subset of case markers in subordinating function. UVs form an open class which can be expanded by lexical borrowings. They cover, by and large, the semantic area covered by members of the verb class in European languages. In addition, they also express notions of property (e.g. colour) and state, and of spatial configuration (thus corresponding also to adverbs, verbal particles and adpositions in other languages).

Not surprisingly given the closed-class nature of IVs, the Jaminjung translation equivalents of most verbs in a language like English are complex

\footnotetext{
${ }^{2}$ Since there is no infinitive form of the inflecting verb in Jaminjung and roots are not produced in isolation by speakers, the 3rd person singular subject $(+3$ rd person singular object for transitive verbs) past perfective form of inflecting verbs is used as citation form throughout, as this is one of the most frequent forms.
} 
predicates, consisting of an IV and a UV. These combinations meet the widely accepted definition (see e.g. Butt 1997: 108) of Complex Predicates as monoclausal constructions (confined to a single intonation unit) where two or more predicative constituents jointly contribute to the argument structure of the clause, share at least one argument, and share values for tense, aspect, modality and polarity; for details on these points, see Schultze-Berndt (2000: Ch. 3). While IV and UV are clearly distinct phonological words, they constitute a close-knit formal unit: they are usually immediately contiguous, with the UV preceding the IV, although the reverse order is also possible. In terms of both their lexical semantics and their argument structure they form nuclear junctures (or "merger" constructions, in the terminology of Baker and Harvey (2010)). While IV and UV can have different argument structures, there is a requirement for all available arguments of the two components to be fused, in other words, neither of the components can introduce an additional participant that would duplicate a grammatical function already contributed by the other, as would be the case e.g. for two bivalent predicates each taking different objects. Usually, the valency of the IV includes or equals that of the UV; the reverse case will be discussed in Section 3.2.3 (see Schultze-Berndt 2000: Ch. 4 for details). As is also to be expected in the case of a closed class, IVs tend to have generic, schematic meanings, and in fact can be regarded as classificatory (McGregor 2002; Schultze-Berndt 2000: Ch. 5; Silverstein 1986): they specify the general type of event that the complex predicate encodes, irrespective of the more specific semantic relationship between UV and IV, which is variable.

Examples (5), (6) and (7) illustrate verbal clauses with simple and complex predicates, respectively. The generic verb of caused locative relation ganarrany 'put' is illustrated in (5) as a simple predicate and in (6) in a complex predicate encoding a specific type of placement, i.e. covering. The IV ganangu, with a generic meaning of manipulation and contact, can simply be translated as 'get' in (5) and in (7) categorises a specific type of impact involving continuous contact, i.e. digging.

$$
\begin{aligned}
& \text { Janggagu gan-arra-ny } \\
& \text { above 3SG.A>3SG.P-IV.put-PST } \\
& \text { jalig-di gurrany yana-ngu. } \\
& \text { child-ERG NEG IRR:3SG>3SG-IV.get/handle }
\end{aligned}
$$

'She put it on top so the child would not get it.'

(6) Nami-ni ngayiny 2SG-ERG meat larriny-ni. bard-bard ngantha-rra-m RDP-UV.cover 2SG.A>3SG.P-IV.put-PRS 
paperbark-ERG/INST

'You cover the meat with paperbark.'
gurr yirra-ngu
UV.dig
1PL.EXCL.A
'We dug [up water].'

In non-finite subordinate clauses, but not in independent clauses, UVs can function as the main predicate without an IV. This is illustrated with the purposive clause in (8).
$n g a-b$-arrga
ngiyina babiny-guluwa [yirrgbi-wu].
1SG>3SG-POT-IV.approach
DIST
elder.sister-KIN2 [UV.talking-DAT]
'I'm going up to your older sister there for talking.' (i.e. for a chat, or an elicitation session)

Apart from non-finite subordinate clauses, Jaminjung has a general finite subordinate clause type which can function both as a temporal or conditional adverbial clause and as a relative clause.

\section{Valency patterns}

The lexicalisation of inherently predicative parts of speech in two distinct classes raises the question of what should be considered "verbs" for the purposes of the comparative investigation of valency. Coding frames, by definition, can only be established for independent predicates, i.e. either IVs on their own or complex predicates, because only they appear with actual argument encoding expressions (both case-marked NPs and indexing morphology). This section and the following Section 4, therefore, describe valency patterns and alternations, respectively, for independent predicates involving IVs. However, as we will see in more detail in Section 5, covert predicate classes based on valency alternations are best investigated for the open lexical class of predicates (UVs), for which alternations are mainly achieved by changes in the IV combining with the same UV.

\subsection{Default encoding with intransitive, transitive and ditransitive predicates}

From the point of view of indexing morphology, inflecting verbs (IVs) fall into two non-overlapping classes. Morphologically transitive verbs in their nonreflexive/reciprocal form occur with a set of pronominal prefixes which 
always index the most agentive argument (A) and in addition the patient-like (P) argument. They represent macro-roles in the sense of Foley and Van Valin's (1984) Actor and Undergoer, or Dowty's (1991) Proto-Agent and ProtoPatient. The order of prefixes is usually A followed by $\mathrm{P}$, although in some cases a portmanteau prefix is used. The $3^{\text {rd }}$ person singular object $(\mathrm{P})$ is not overtly expressed except with a $3^{\text {rd }}$ person singular subject.

Morphologically intransitive verbs indicate their single argument (S) by a pronominal prefix which in most cells of the paradigm (except $2^{\text {nd }}$ person singular) is identical to the A prefix. Thus, indexing, not unexpectedly, more or less follows a nominative-accusative pattern. Typical transitive and intransitive predicates are shown in (9) and (10), respectively.

$$
\begin{aligned}
& \text { Gugu=biyang burrb burru-minda-ny jalig-ni. } \\
& \text { water=SEQ finish 3PL.A>3SG.P-eat-PST child-ERG }
\end{aligned}
$$

'Then the children finished / drank up all the water.'

$$
\begin{array}{llll}
\text { Thanthu=biya } & \text { ngayiny } & \text { bunburr } & \text { burr-angga. } \\
\text { DEM=SEQ } & \text { animal } & \text { many.take.off } & \text { 3PL.S-go.PRS }
\end{array}
$$

'Those animals all take off.'

An additional indexing phenomenon is the cross-referencing of dative, locative and allative arguments or adjuncts by an enclitic oblique (dative) pronoun. This "clitic doubling" is mainly restricted to animate referents.

$$
\begin{aligned}
& \begin{array}{l}
\text { Gan-anyjam }=n u \quad \text { buru jalig-gu. } \\
\text { 3SG>3SG-bring.PRS=3SG.DAT return } \\
\text { child-DAT }
\end{array} \\
& \text { 'She brings it (food) back for the child. }
\end{aligned}
$$

As examples (9) and (10) also show, case marking follows ergative-absolutive alignment (with optional ergativity; see Section 4.1). As a general rule, the case frame used with a particular predicate, whether simple or complex, follows from the morphological transitivity of the IV. That is, a single absolutive argument occurs with intransitive IVs, and an ergative-absolutive case frame (or double absolutive if ergative marking is omitted) can be used with morphologically transitive IVs.

In one case, that of the polyfunctional IV ganiyu 'say/do', which functions as framing verb with quotations, the quotation takes the position of the absolutive P argument, as illustrated in (20) below. Optionally, the addressee can be represented by a dative-marked NP and/or by the dative pronominal clitic; however, since on formal grounds addressees or recipients encoded in this way cannot be distinguished from benefactive adjuncts (as in (11)), they are not considered as core arguments for the purpose of this paper. Further 
divergences from the ergative-absolutive case frame with morphologically transitive IVs, i.e. mismatches between the case frame and indexing morphology, will be discussed in Section 3.2.

Ditransitive predicates involve morphologically transitive IVs but license an additional absolutive argument, i.e. they take two absolutive objects corresponding to the theme-like $(\mathrm{T})$ and the recipient-like $(\mathrm{R})$ participant. Indexing typically follows a "secondary object" (Dryer 1986) or "secundative" alignment (Haspelmath 2005; Malchukov et al. 2010), that is, the recipient-like participant $(\mathrm{R})$ rather than the theme-like participant $(\mathrm{T})$ is indexed by the $\mathrm{P}$ prefix of the inflecting verb (exceptions are discussed in Section 4.2). An example of a ditransitive predicate is the complex verb burlug ganingarnany 'give to drink', illustrated in (12) with its two absolutive objects.

$$
\begin{array}{llll}
\begin{array}{l}
\text { Ngayug=biya } \\
\text { ti=binji }
\end{array} \text { ba-wun-ngarna } & \text { burlug. } \\
\text { 1SG=SEQ } & \text { tea=only } \quad \text { IMP-2DU.A>1SG.P-give } & \text { drink } \\
\text { 'Me, give me only tea to drink, you two.' } &
\end{array}
$$

Reflexive-reciprocal forms are productively formed from morphologically transitive IVs which consequently become morphologically and syntactically intransitive, i.e. they take the intransitive pronominal prefix, and the $\mathrm{A}=\mathrm{P}$ is encoded by an absolutive noun phrase (see Section 5.1).

\subsection{Divergent encoding frames}

While generally (with the exception of ditransitive predicates) the morphological transitivity of a given IV corresponds to the syntactic transitivity in a clause involving this IV as simple predicate or part of a complex predicate, some mismatches do occur; these are the topic of this section.

\subsubsection{Ergative marking with an intransitive inflecting verb}

The first mismatch concerns one of the five morphologically intransitive IVs, garna 'burn, be affected by heat'. As example (13) shows, the heat source can be encoded by an NP marked with ergative/instrumental case which is not indexed on the verb.

$$
\begin{aligned}
& \text { ya-nj-irna buna-ni! } \\
& \text { IRR-2SG.S-burn ashes-ERG/INST } \\
& \text { 'The hot ashes might burn you! / You might get burnt by the hot } \\
& \text { ashes!' }
\end{aligned}
$$


This IV has a transitive counterpart, ganirriga 'cook, burn', which in contrast to garna 'burn' usually takes an animate agent, although the sun is also attested as agent with this verb. It is argued in Schultze-Berndt (2000: 167, 75-77) that the ergative/instrumental case encodes the role of 'effector' in the sense of Van Valin and Wilkins (1996), subsuming instruments, natural forces, and agents, while the A prefix on transitive verbs encodes the 'ultimate cause' or 'first cause' of an event (see e.g. DeLancey 1991; Van Valin \& LaPolla 1997: 146). Thus, the situation of an inanimate natural force as an agent, as in (13), does not warrant the encoding as ultimate cause, and therefore does not license the use of a transitive verb with its A prefix.

\subsubsection{Morphologically transitive inflecting verbs in semantically monovalent complex predicates}

Other mismatches are related to the fact that IVs can take on secondary meanings or become semantically "bleached" in some types of complex predicate. For example, the morphologically transitive IV ganimangu 'hit' occurs in syntactically intransitive complex predicates encoding a type of appearance or emerging, as illustrated in (14). In these cases, the P prefix of the IV invariably takes the third person singular form.

$$
\begin{aligned}
& \text { Julag=biyang bul gani-mangu=nu. } \\
& \text { bird=SEQ emerge 3SG.A(>3SG.P)-hit.PST=3SG.DAT }
\end{aligned}
$$

Similarly, the multifunctional verb ganiyu 'say/do' forms syntactically intransitive complex predicates with some UVs of manner of motion as in (15), as well as with UVs of internal motion, emotional condition, and internally caused change of state. This IV is used more generally as a verb indicating internal causation, and can be regarded as less than fully transitive, since it does not allow reflexive/reciprocal marking.

$$
\begin{array}{ll}
\begin{array}{l}
\text { Jalig=biyang } \\
\text { child=SEQ }
\end{array} & \text { yugung } \\
\text { run } & \text { 3SG.Ani-yu. }
\end{array}
$$

'The child ran off.'

\subsubsection{Syntactically transitive activity expressions with morphologically intransitive inflecting verbs}

The final type of mismatch between morphological and syntactic transitivity to be discussed here is the converse of the former: semantically transitive 
complex predicates are formed with the morphologically intransitive verbs gagba 'be' or gajgany 'go' in their secondary function of marking atelicity, as in (16).

$$
\begin{array}{llll}
\text { En janyungbari } & \text { burlug-mayan } & g a-y u & g u g u . \\
\text { and another(ABS) } & \text { drink-ITER } & \text { 3SG.S-be.PRS } & \text { water(ABS) } \\
\text { 'And the other one (animal) is drinking water.' } &
\end{array}
$$

Such complex predicates often, but not always, have an alternant with a morphologically transitive IV (see Section 5.3). Unlike with true transitive complex predicates, however, the A in combinations with these two intransitive verbs is never ergative-marked, i.e. these predicates only occur with a double absolutive frame.

\subsubsection{External possessor constructions}

Jaminjung exhibits the phenomenon of external possession with body parts, that is, if a body part is involved as the single participant or the patient of an event, the possessor is the core argument in terms of indexing morphology, and the body part itself is added as an additional absolutive argument, as shown in (17). While this phenomenon also results in an impression of mismatch between morphological transitivity and the number of syntactic arguments, it is not considered an alternation here.

$$
\begin{aligned}
& \begin{array}{l}
\text { ngamayag-di gan-birri-m burru } \\
\text { diarrhoea-ERG }
\end{array} \text { 3SG.A>1SG.P-bite-PRS belly } \\
& \text { 'My belly hurts because of diarrhoea'; lit. 'The diarrhoea is biting me } \\
& \text { (with respect to the) belly.' }
\end{aligned}
$$

\section{Uncoded Alternations}

Jaminjung exhibits only few types of uncoded alternation, i.e. alternations manifested only in the choice of argument marking. The first one concerns different options of marking agents as ergative, absolutive (zero-marking), or ablative (Section 4.1). The second one is a marginal alternation in encoding of theme and recipient with ditransitive predicates (Section 4.2). A further type of alternation, a choice between allative-marked and locative-marked goals with certain predicates subcategorising for a Location, can also be analysed as an uncoded alternation, but is not further considered here because it does not involve a core argument. Since noun phrase arguments can generally be 
omitted when reconstructable from discourse, there are no grounds for identifying any "omission" alternation of the type eat $X$ vs. eat.

\subsection{Alternations involving agent marking}

In Jaminjung, there is a three-way alternation in agent marking with syntactically transitive (and ditransitive) predicates: since the language exhibits optional ergativity, agents can be ergative-marked or unmarked (i.e. in the absolutive). Moreover, the ablative case also functions as an agent marker in certain cases. Both possibilities are discussed here in turn.

Optional ergativity is a phenomenon now widely attested in the languages of the world, including Australian languages (for an overview, see McGregor 2010). Unlike in split ergative systems, there is no clear grammatical factor responsible for the absence or presence of ergative marking, although the factors identified for split systems account for some of the alternations observed. Thus, in Jaminjung, absence of ergative marking can be related to the animacy of A (with pronominal Agents, in particular, less likely to be ergative-marked) as well as to verb class, with less "effective" verbs in the sense of Tsunoda (1981) (e.g. 'have', 'see', 'say/do' + quotation) less likely to appear with ergative-marked NPs. Moreover, focal rather than topical Agents tend to be ergative-marked, and discourse pragmatic factors come into play as well, in that absence of ergative-marking can be employed by speakers to downplay the agentivity of A or the effect of an event, in a similar way to that identified for Gooniyandi by McGregor (see also McGregor 1992; McGregor 1998). This is illustrated in (18) and (19). The absence vs. presence of ergative marking with predicates using the same IV in the two examples is most likely explained with the difference in impact between a pet frog leaving its 'owner' (18) and a mother leaving her child (19). In a text count (Schultze-Berndt 2006), it was found that more than $30 \%$ of overt A noun phrases are not marked for ergative.

$\begin{array}{llll}\begin{array}{l}\text { Malara=biya } \\ \text { frog=SEQ }\end{array} & \text { dibard } & \text { ganuny-ngunga-m, } & \text { ba-ngawu. } \\ & \text { jump } & \text { 3SG.A>3DU.P-leave-PRS } & \text { IMP-see }\end{array}$

'The frog now is leaving the two jumping away, look.' (from a Frog Story)

$$
\begin{aligned}
& \begin{array}{l}
\text { Majani gujarding-ni waj } \\
\text { maybe mother-ERG leave.behind }
\end{array} \text { 3SG.Anga-m. } \\
& \text { 'Maybe the mother leaves her (a child).' }
\end{aligned}
$$


A second complicating factor regarding the marking of Agents in Jaminjung is the existence of a second ergative case, formally identical to the ablative case. Ablative agent marking is very infrequent and is mainly used to indicate unexpected or contrastive agents, similar to the focal ergative marker in Warrwa (McGregor 2006). A good example of unexpectedness, from a narrative, is the case of a kangaroo which starts to speak to the men hunting it, in (20).

$$
\begin{aligned}
& \text { "nanggayan guny-bi-yarluga?" } \\
& \text { who 2DU.A>3SG.P-POT-poke } \\
& \text { gani-yu=bunyag, } \\
& \text { 3SG.A }>3 S G . P-s a y / \text { do.PST=3DU.DAT kangaroo-ABL=GIVEN } \\
& \text { '“Who do you want to spear?" it said to the two, the kangaroo did.' }
\end{aligned}
$$

\subsection{Alternations involving ditransitive predicates}

The clearest case of an uncoded alternation, though marginal in terms of its frequency, is the indexing of either the recipient or the theme of ditransitive predicates on the verb. This phenomenon is discussed in more detail in Schultze-Berndt (2010) and only briefly outlined here.

Ditransitive inflecting verbs like ganingarnany 'give' as well as certain complex predicates are syntactically ditransitive in that they allow for two absolutive objects (see Section 3.1). However, the inflecting verbs occurring in these expressions are morphologically transitive in that they take the $\mathrm{A}>\mathrm{P}$ pronominal prefix. Therefore, only one of the objects can also be indexed on the verb. Usually, the Recipient of ditransitive predicates is the primary object in terms of indexing, as shown in (21). Only in the rare case of animate themes (e.g. in the context of 'giving' in marriage, or conversely, robbing someone of a spouse, as in (22)) or otherwise highly salient themes (e.g. traditional country as in (24)) the theme may be (but is not necessarily) indexed instead. (Due to the scarcity of examples it is not clear whether the recipient takes dative or absolutive case).

$\begin{array}{llll}\text { Majani bun-bu-ngarna } & \text { buru ngayiny, majani gara. } \\ \text { maybe } & \text { 3PL.A>1SG.P-POT-give } & \text { return meat maybe nothing }\end{array}$ 'Maybe they are going to give me back some meat, maybe not.'

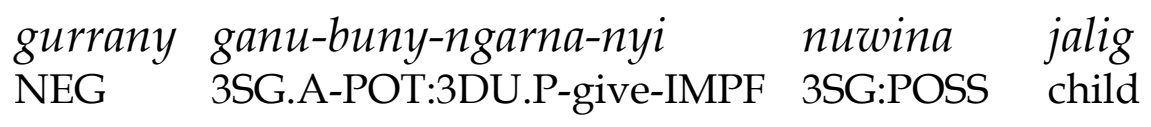
'He wouldn't give (him) the two, his children' (it is clear from the context that a potential father-in-law refuses to give his two 
daughters to a specific man; in isolation this sentence could also mean 'he wouldn't give the two (men) his child'.

Examples (23) and (24) show the ditransitive alternation with a complex predicate, yurrg ganarrany 'show'.

$$
\begin{array}{lll}
\text { Yurrg } & \text { gan-garra-ny } & \text { ngayug. } \\
\text { show } & \text { 3SG.A:1SG.P-put-PST } & \text { 1SG }
\end{array}
$$

'She showed (it) to me.' (Lit. 'She showed me'; referring to yam root)

$$
\begin{array}{llll}
\text { Yurrg } & \text { nga-rra-m=ngunggu } & \text { yagbali } & \text { Ngaliwurru } \\
\text { show } & \text { 1SG.A:3SG.P-put-PRS=2SG.DAT } & \text { place } & \text { Ngaliwurru }
\end{array}
$$

'I'm showing you the Ngaliwurru country.'

\section{Verb-coded alternations (Voice alternations and valency change)}

As already indicated above, the division of predicative lexical items into two distinct parts of speech - inflecting verbs (IVs) and uninflecting verbs (UVs) or coverbs - has important ramifications for the grammatical structure, including argument structure of Jaminjung. As we have already seen in Section 4, uncoded alternations only play a marginal role in this language. Verb-class sensitive alternations mainly manifest themselves in the choice of different inflecting verbs with the same UV, to be discussed in Section 5.2. Other valency-changing inflectional markers (e.g. passive or antipassive) or derivational mechanisms (e.g. causative, applicative, middle forms) are completely absent from the grammar of Jaminjung. The only case of an alternation which is morphologically encoded on the inflecting verb is the reflexive-reciprocal alternation, discussed in Section 5.1.

\subsection{Reflexive-reciprocal marking with transitive verb roots}

All morphologically transitive IVs except for ganiyu 'say/do' can take a suffix -ji -ja which encodes both the reflexive and reciprocal function in the narrow sense. That is, its use is restricted to agents acting upon themselves, or multiple agents acting upon each other. It thus has no additional functions such as middle or inchoative marking. In complex predicates, the productivity of reflexive/reciprocal marking is only constrained by considerations of semantic compatibility. 
Formally, reflexive/reciprocal marking results in both morphological and syntactic intransitivity of the IV, i.e. the verb takes the intransitive paradigm of pronominal prefixes, and a single absolutive argument in the function of $\mathrm{A}=\mathrm{P}$. The reflexive of a transitive complex predicate is illustrated in (25) (see example (6) for the underived counterpart); an example in reciprocal interpretation is (26) (compare this with (28)e).

Bard-bard

ga-rra-ja=burrinyi, 3SG.S-put-REFL.PST=3DU

bagarli-ni. paperbark-ERG/INST

'He covered himself (with negative effect) on the two, with paperbark.' (Referring to a (mythical) man going into hiding to be able to surprise and assault two women.)
Marlayi gurdurru-ni
burru-ma-ja.
woman fighting.stick-ERG/INST 3PL.S-hit-REFL.PST

'The women fought (lit. 'hit each other') with fighting sticks.'

\subsection{Alternations by change of inflecting verb}

In this section, we will consider verb-class sensitive alternations which operate at the level of the complex predicate, but identify semantically based predicate classes within the open-class lexical predicate type of Uninflecting Verb (UV). This is because the alternations are brought about by the opposition of different inflecting verbs (IVs) with the same UV; they are thus unavailable to IVs themselves. ${ }^{3}$ This type of alternation is treated here as "coded alternation" since it is marked - albeit not by morphological means - within the verbal complex. There is no "basic" alternant in the sense that it has no coding - the alternants are simply coded differently, by the choice of a different IV (this does not mean that the UV itself does not have a basic valency; on this issue see further below).

The semantic effect of a change of IV with the same UV is not restricted to valency change. Rather, different IVs can also be employed to indicate differences in lexical aspect (aktionsart), differences in deictic direction in the case of some predicates of motion, and differences in the types of instrument employed with certain predicates of activity or accomplishment. The choice of

\footnotetext{
${ }^{3}$ Simple verbs may have formally unrelated (or only diachronicaly related) lexical alternants (comparable to the causative-inchoative pair kill-die in English), usually in an equivalent opposition to that at the basis of the telicity alternation described in Section 5.3. An example is the pair ganimindany 'eat' (transitive IV) vs. thawaya gagba 'be eating' (with intransitive IV 'be' used with a general meaning of atelicity).
} 
IV could even be responsible for more subtle differences in predicate semantics and event structure between the resulting complex predicates, which may or may not affect the valency of the resulting complex predicate. Example (27) illustrates a difference in aktionsart, but not in argument structure, brought about by the choice of one of two different IVs. The UV in this example is wurlurlu 'enter/go inside, of multiple entities'; the complex predicate formed with gajgany ' go' is interpreted as an accomplishment (locomotion preceding the entering), while the equivalent formed with gardbany 'fall' is interpreted as an achievement (this IV, despite its gloss, does not entail downward motion). The pattern illustrated here is available to a number of other UVs expressing either a position or a change of position or location, e.g. walthub 'be inside', bagurr 'be inside an open container', malang 'cross, go across'. In other words, the combinatorial possibilities of UVs with IVs serve to define semantically coherent predicate classes (of UVs), in this case the class of UVs of 'boundary crossing'.
a. Wurlurlu
yurra-ngga intit jarriny-gi enter(PL) 1PL.INCL.S-go.PRS TAG cave/house-LOC 'Let's go inside the house, right?'
b. Jarlig child wurlurlu
enter(PL) burr-irda-m (gurrurrij-gi). 3PL.S-fall-PRS car-LOC

'The children are getting in (the car).'

Of the many alternations involving regular collocational patterns of IVs with the same semantically coherent subsets of UVs we will only consider here those resulting in a change of valency, and of those only the most salient ones (either in terms of productivity or in terms of typological interest). More detail on classes of UVs and full justification of the classification can be found in (Schultze-Berndt 2000: Ch. 6).

Before discussing the individual cases of alternations, it is worth making explicit the criteria for establishing the valency and aktionsart of IVs. This is not a trivial question, since UVs do not occur in a full coding frame on their own (only with IVs). The main evidence for the basic valency of UVs is therefore their combinatorial potential with IVs. This approach is based on the assumption of monosemy and monotonicity (i.e. the assumption that compositional operations do not remove meaning components). Taking the UV wurlurlu in (27) as an example, it can be considered monovalent rather than bivalent since it allows a combination with intransitive IVs. However, unlike its near-equivalent walthub 'be inside, of single entity', it is not stative, but dynamic, since it does not allow the combination with the stative 
intransitive IV gagba 'be'. Based on the evidence in (27) and similar attestations, we can further conclude that wurlurlu is an achievement predicate, i.e. only encodes a change of location. The IV gardbany 'fall' thus does not add any semantic component to the complex predicate, it merely serves as IV compatible with the UV in an complex predicate expressing achievement. The IV gajgany 'go' on the other hand adds the semantic component of locomotion and thus turns the resulting complex predicate into an accomplishment.

The first main set of alternations to be discussed below (Sections 5.2.1 to 5.2.5) all exhibit a causative-inchoative(-stative) pattern $(\mathrm{S}=\mathrm{P})$, the second set (Sections 5.2.6 to 5.2.8) a non-causative transitivity alternation pattern $(S=A)$, and the remaining sections (5.2.9 to 5.2.11) are devoted to various other alternations.

\subsubsection{Causative-inchoative alternation with predicates of externally caused change of state}

One of the most productive alternations is the equivalent of the causativeinchoative alternation, restricted to externally caused change of state predicates (in the sense of Levin \& Rappaport Hovav (1995)) such as bag 'break'. Formally, UVs of externally caused change of state are defined by the property, unique to members of this class, of forming inchoative complex predicates with the intransitive verb gajgany 'go' in a secondary sense of 'state change', but not with other locomotion verbs. Interestingly, all UVs that meet this formal criterion encode a change of state which leads to some kind of abnormal result state, usually irreversible and undesirable, i.e. destruction or destabilisation. With these UVs, a causing event can be specified; this can be encoded by an intransitive IV (e.g. gardbany 'fall' to express a change of state arising from contact with a location, or garna 'burn' to express change of state resulting from heat), or, in the transitive causative alternants, by one of several transitive IVs expressing contact and force with different types of instruments or trajectories of impact. The full range of possibilities is illustrated in (28) for bag 'break'.

(28) a. A:;

$$
\begin{array}{llll}
\text { A:, } & \text { bag } & \text { ga-jga-ny=ni } & \text { bottle. } \\
\text { ah } & \text { break } & \text { 3SG.S-go-PST=SFOC } & \text { bottle }
\end{array}
$$

'Ah, the bottle broke.' (Frog Story)

b. Miri bag buny-b-irdbaj. upper.leg break 3DU.S-POT-fall 
'The two are going to fall so that they break a leg.'

c. Wurlug=gung ga-rna-ya bag alone=RESTR 3SG.S-burn-PRS break

'It breaks by itself through burning.' (log in fire)

d. Nawij bag burr-angga-m. neck break 3PL.A>3SG.P-get/handle-PRS

'They break its neck (by strangling it).' (bird)

e. Miri bag burra-ma-nyi gurrubardu-ni. upper.leg break 3PL.A>3SG.P-hit-IMPF boomerang-ERG/INST 'They used to break their legs with a boomerang.' (kangaroo)

f. Majani bag yanth-ina thanthu mali. maybe break IRR:2SG.A>3SG.P-chop DEM thing '(Don't throw a stone), maybe you will break that thing (with an edge).' (tape recorder)

g. Nga-w-inama bag, bijjingman. 1SG.A>3SG.P-POT-kick/step.IMPF break moist

'I wanted to break it with my foot, (but it was still) fresh (and therefore too strong).' (firewood)

h. Jurruny-ni bag gan-ijja-ny. hand-ERG/INST break 3SG.A>3SG.P-poke-PST

'He broke it by poking with his finger.'

i. Bag gan-ardgiya-ny langiny-bina. break 3SG.A>3SG.P-throw-PST wood-ALL

'She broke it by hitting it against another branch.' (firewood)

j. Bag gan-uga barrigi.

break 3SG.A>3SG.P-take.PST fence

'It (the bull) broke (out of) the fence.' (at a rodeo)

k. Guyuwarn bag nga-rra-ji.

bone break 1SG.S-put-REFL

'I broke a bone.'

UVs of externally caused state change such as bag are analysed here as monovalent and telic - the former, because they may occur with intransitive UVs, the latter, because they cannot combine with the stative IV gagba 'be'. Thus, bag means 'break', not 'be broken'. Under this analysis, the causative 
alternants are 'derived', in comparison with the inchoative alternants, in that the second argument in the causative alternants is added by the IV, and not inherent to the UV. A subset of those monovalent UVs of externally caused state change showing the same patterns of alternations as bag 'break' is shown in Table 1.

Table 1. Monovalent Uninflecting Verbs (UVs) of externally caused change of state

$\begin{array}{ll}\text { bag } & \text { break (into pieces) } \\ \text { garl } & \text { break } \\ \text { ning } & \begin{array}{l}\text { 1. break (in two parts), break off } \\ \text { 2. stop, finish, die }\end{array} \\ \text { lag } & \begin{array}{l}\text { split, crack } \\ \text { bily }\end{array} \\ \text { gad } & \text { cut, get cut } \\ \text { jibug } & \text { get a hole } \\ \text { lum } & \text { swell up } \\ \text { jinku } & \text { go down (e.g. swelling, fire) } \\ \text { digirrij } & \text { 1. die } \\ & \text { 2. really suffer, get badly severed } \\ \text { burrb } & \text { finish, run out }\end{array}$

\subsubsection{Causative-inchoative alternation patterns with predicates of change of location and motion}

In contrast to "pure" change of state predicates (discussed in the previous Section), predicates of change of location and motion are compatible with verbs of locomotion (i.e. both gajgany 'go' and garumany 'come'), as well as with gardbany 'fall', in the inchoative alternant. The causative alternants are mainly formed with the transitive IVs ganangu 'get, handle, manipulate', expressing removal from a location, and ganarrany 'put' expressing placement in a location (i.e. this IV semantically entails that an endpoint is reached), but also with specific IVs encoding a manner and trajectory of impact, depending on the specific semantics of the UV.

One of the subclasses undergoing this type of alternation are predicates of severance, listed in Table 2 and illustrated with $j a b$ 'detach attached point of long flexible entity e.g. feather, hair or grass' in (29).

$\begin{array}{cll}\text { (29) } \begin{array}{ll}\text { a. Wirra } \\ \text { hair }\end{array} & \text { jab } & \text { ga-ram. } \\ & \text { detach } & \text { 3SG.S-come.PRS }\end{array}$ 
'Her hair is coming out.'

b. Warnda=biyang jab-jab burra-mila (mayi-ni) grass=SEQ RDP-detach 3PL.A>3SG.P-get/handle.IMPF man-ERG 'Then the men used to pull out grass.'

Table 2. Monovalent UVs of severance

larara separate, go separate ways (of multiple animates)

bawu open up, go into the open, get out

gub come out, come off (general)

jab get detached, of long entity attached with its end point (e.g. hair, grass)

dirawu peel off

UVs of path and direction motion, likewise, form their inchoative alternant with any intransitive verb of motion, and their causative alternant (mostly) with ganarrany 'put'. The alternation is illustrated in (30) with burduj 'move upwards'; a representative list of UVs from this class is in Table 3.
a. Burduj ga-jga-ny langiny-bina jayiny ngarrgina. go.up 3SG.S-go-PST tree-ALL MoMo/DaCh 1SG:POSS
'My grandchild climbed up a tree.'
b. (Jalig-di) burduj gan-arra-m thanthu C. child-ERG go.up 3SG.A>3SG.P-put-PRS DEM <proper.name> '(The child) is lifting that $\mathrm{C}$ up (into the car).'

Table 3. Monovalent UVs of path / direction of motion

$\begin{array}{ll}\text { burduj } & \text { climb up, move upwards } \\ \text { jid, jag } & \text { move downwards } \\ \text { buru } & \text { return, go back } \\ \text { walig } & \text { move in a circle-shaped path, move around } \\ \text { yirrbag } & \text { move over, shift place } \\ \text { wurlurlu } & \text { enter (of multiple participants) }\end{array}$

Finally, UVs of ballistic motion (listed in Table 4) mainly form their inchoative alternant with gardbany 'fall' and their causative alternant with ganardgiyany 'throw' or ganiyu 'say/do', but sometimes also other transitive verbs. For example, the UV lawu 'spill, pour' in combination with ganiyu 'say/do' simply expresses caused dispersal of a liquid, but in combination with ganarrany 'put' a goal-oriented transfer, i.e. the pouring of a substance into a container. 
(31)

$\begin{array}{lll}\text { a. Lawu } & \text { ga-rda-m } & \text { gugu. } \\ \text { spill/pour } & \text { 3SG.S-fall-PRS } & \text { water }\end{array}$

'The water pours/spills.'

b. Lawu gani-yu ngabulu janju-ni jalig-ni. spill/pour 3SG.A>3SG.P-say/do.PST milk DEM-ERG child-ERG

'The child spilled the milk.'

c. [Nalija] lawu nga-w-arra=gunyag, birrigud-gi. [tea] spill/pour 1SG.A>3SG.P-POT-put=2DU.DAT tin-LOC 'I will pour it [the tea] for you two, in the tin.'

Table 4. Monovalent UVs of ballistic motion

$\begin{array}{ll}\text { didid } & \text { roll } \\ \text { diny } & \text { lie down, fall over } \\ \text { jarndang } & \text { get down } \\ \text { buwu } & \text { enter water } \\ \text { dulb } & \text { fall of multiple entities (e.g. of dust, leaves) } \\ \text { burrurrug } & \text { scatter, get scattered } \\ \text { lawu } & \text { spill, pour }\end{array}$

\subsubsection{Causative-inchoative alternation with predicates of application of} heat

An good illustration of how valency alternations are interwoven with the specific semantics of IVs comes from a class of monovalent predicates encoding conventionalised, culture-specific ways of applying heat. This includes not only manner of cooking, but also drying, applying heat or smoke for medicinal purposes and ritual cleansing, and the (usually deliberate) lighting of bush fires. For example, the UV murl 'heat with hot ground or stones' can describe both roasting of food in a ground oven (with stones), and heating parts of the human body by means of hot ground for medicinal purposes. None of these UVs entails that a state of change results from the application of heat (e.g. consumption by fire), although a number of them may convey, by implicature, the interpretation that the cooked, edible state of food is reached. UVs from this class combine with IVs garna 'burn' as well as with

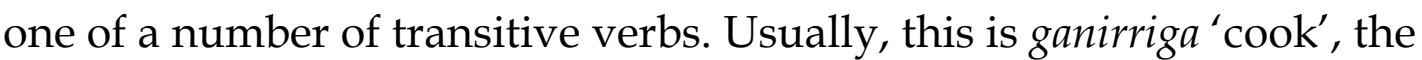
transitive equivalent of garna 'burn' (see also Section 3.2.1). Both verbs are illustrated in (32) with the coverb bum 'apply smoke'; in addition a second transitive IV ganima 'hit' in its secondary sense of 'totally affect' is shown in combination with the same UV. 
(32)
a. julany-ni
bum
burr-irna
smoke-ERG/INST
apply.smoke 3SG.S-burn.PST

'They cleaned themselves with smoke.' (cleansing ceremony after the death of a relative)
b. bum burru-rriga burrb gurrurrij apply.smoke 3PL.A>3SG.P-cook.PST finish car

'They finished smoking the car.' (cleansing ceremony)

$\begin{array}{llll}\text { c. } \mathbf{b u m} & \text { yirri-ma } & \text { motika, } & \text { bula } \\ \text { apply.smoke } & \text { 1PL.EXCL.A>3SG.P-hit.PST } & \text { car } & \text { track }\end{array}$

'We smoked the car, the traces (of the deceased).'

Table 5. Monovalent UVs of application of heat

$\begin{array}{ll}\text { murl } & \text { 'roast', heat by means of hot ground or stones, usually in ground oven } \\ \text { bud } & \text { cook on coals or in hot ashes } \\ \text { bum } & \text { apply smoke (e.g. in ritual cleansing), surround with smoke } \\ \text { marl } & \text { apply s.th. hot (e.g. stones for cooking, or hot bandage) } \\ \text { gumarl } & \text { burn (of country), burn as a bushfire }\end{array}$

\subsubsection{Causative-inchoative alternation with predicates of internal causation}

In Jaminjung, predicates of internal causation have the characteristic property of being formed with the IV ganiyu 'say, do' in a monovalent reading (see Section 3.2.2). This category includes predicates of sound emisson, speech act, internal motion, and bodily or emotional condition, as well as predicates of internally caused state change such as luba ganiyu 'grow', lit. 'become big'. Most of the UVs involved do not undergo any valency alternations, but some of them (listed in Table 6), notably those of bodily or emotional condition, occur in causative complex predicates formed either with the IV ganangu 'get, handle' in a reading of non-physical manipulation, as in (33), or with the IV ganimiliny 'make' which otherwise is rarely used as a causative verb.
a. Ngayug=gayi
bujarl
nga-yunggu-m,
Nangari-wu. $1 S G=A L S O \quad$ sad/sorry $1 S G . A(>3 S G . P)$-say/do-PRS subs.name-DAT 'I too am worried for / sad about Nangari.'

b. Bujarl guny-ngangga-m. sad/sorry 2DU.A>3SG.P-get/handle-PRS

'You two make her sad.' 
Table 6. UVs of internal causation which occur in a causative-inchoative alternation

$\begin{array}{ll}\text { bujarl } & \text { 'be(come) / make someone sad, sorry' } \\ \text { wangarr } & \text { 'be(come) / make someone mad, silly, out of one's mind' } \\ \text { birdinyiny } & \text { 'rotate, spin, turn round and round' (intr./tr.) } \\ \text { jili } & \text { 'stir, move' (intr.), 'wake someone up' (tr.) }\end{array}$

\subsubsection{Causative-inchoative-stative alternation with predicates of spatial configuration}

A very productive pattern of alternations is found with stative UVs expressing a position, posture, location, or configuration. These regularly occur with four IVs: gayu 'be' (stative intransitive alternant), ganimuwa 'have' (stative transitive alternant), gardbany 'fall, change locative relation' (inchoative alternant, not entailing downward motion), and ganarrany 'put, cause to change locative relation' (causative alternant). Thus, expressions of stative position, of entering a position and of induced position are in an equipollent relationship in Jaminjung, that is, none of them is formally derived from the other (although they are all based on a positional UV which is itself monovalent and stative). The pattern is illustrated in (34) for the UV nang 'be in a sticking position, adhere'.
a. nang
$g a-y u$
larriny-gi
stick 3SG.S-be.PRS paperbark-LOC
'It is sticking on the paper.' (stamp)
b. nang-nang=biya burr-irda- $m=n u$. RDP-stick=SEQ 3PL.S-fall-PRS=3SG.DAT
'They (ants) get stuck on it then.' (on echidna tongue)
c. nang burr-arra-m.
stick 3PL.A>3SG.P-put-PRS
'They stick it on.' (stamp)
d. nang gana-ma-ya jurruny-gi stick 3SG.A>3SG.P-have-PRS hand-LOC

'He has it stuck in his hand.' (a lolly)

UVs of spatial configuration undergoing the above alternation form a rather large set, due to the propensity of Jaminjung to lexically encode specific types of configurations. The most frequent monovalent UVs of spatial configuration are listed in Table 7. Bivalent UVs of spatial configuration such as warrgi 'hold 
in front' also undergo an alternation between caused state and causative inchoative, which however does not affect the valency of the resulting complex predicates.

Table 7. UVs of spatial configuration

$\begin{array}{ll}\text { waga } & \text { sit, stay in a place } \\ \text { jalu } & \text { squat, crouch, sit on haunches } \\ \text { jardarda } & \text { kneel, sit/stand on knees } \\ \text { mugurn } & \text { lie, sleep } \\ \text { lula } & \text { lie (multiple entities) } \\ \text { yirrb } & \text { be together, gather around s.o./s.th. } \\ \text { ngamang } & \text { ride, be astride, sit on s.o.'s back or shoulders } \\ \text { balbba } & \text { be side by side, be flat on something, be close together (of two entities) } \\ \text { darl } & \text { lined up, be in a line side by side (of multiple entities) } \\ \text { yarr } & \text { be in one line side by side } \\ \text { mundalung } & \text { back to front, head to toe } \\ \text { warrb } & \text { be together } \\ \text { murruny } & \text { heaped up, in a heap } \\ \text { linkid } & \text { sidewards, on the side } \\ \text { bilwa } & \text { belly up, on the back } \\ \text { mun } & \text { belly down, upside down, bent over } \\ \text { walthub } & \text { be inside, enclosed } \\ \text { bagurr } & \text { be in a flat container with open top (e.g. nest) } \\ \text { jardi } & \text { be full (in a container), be filling out a container } \\ \text { bardbard } & \text { be covered with a layer (e.g. leaves, clothes) } \\ \text { thawu } & \text { be immersed in a liquid, soak } \\ \text { gurdij } & \text { stand (still) } \\ \text { bayirr } & \text { be on top of s.th., be supported } \\ \text { thuward } & \text { lie across, be stretched out across } \\ \text { ngardurdug } & \text { folded (also of clothes), collapsed, crossed (of arms, legs), curled up } \\ \text { dibird } & \text { be wound around s.th., be tied up, be entangled } \\ \text { nang } & \text { stick, adhere to a surface } \\ \text { narrng } & \text { be stuck on/in s.th. } \\ \text { bardag } & \text { joint, be in tight fit } \\ \text { thabba } & \text { be pierced with s.th. such that it protrudes } \\ \end{array}$

\subsubsection{Transitivity alternation with stative UVs $(\mathrm{S}=\mathrm{A})$}

A number of stative UVs participate in a transitivity alternation with noncausative semantics where the $S$ in the intransitive alternant corresponds to the A in the transitive alternant. The UV malangayij 'hear, listen' is of this type. A class of UVs of direction of gaze, listed in Table 8, also exhibits this alternation. In this case, the intransitive alternant is formed with the IV gagba 
'be' and a transitive alternant with ganingawu 'see'. The most frequent and semantically general member of the set is mung 'look at, watch', illustrated in (35). In the (a) example, it is also combined with a second, more specific member of this class, mirrang 'look up'.
a. Wirib
mirrang
mung ga-yu,
ba-ngawu!
dog look.up
look.at
IMP-see

'The dog is looking (at something) looking up, look!' (Frog Story, dog looking at beehive)

b. S.-ni=biya mung ganurra-ngayi-na=ngarndi

name-ERG=SEQ look.at 3SG.A>3PL.P-see-IMPF=SFOC

(yalumburrma).

saltwater.crocodile

'S. then was watching the saltwater crocodiles.' (eating cattle)

Table 8. UVs of direction of gaze

$\begin{array}{ll}\text { mung } & \text { look at s.th., watch } \\ \text { mirrang } & \text { look up } \\ \text { wib } & \text { look back over one's shoulder } \\ \text { ngayirr } & \text { peep in/out, look into/out of a location } \\ \text { riyi } & \text { be alert, look out from somewhere } \\ \text { wiyama } & \text { look out at night (e.g. of owl) }\end{array}$

\subsubsection{Transitivity alternation with UVs of motion $(\mathrm{S}=\mathrm{A})$}

Another well-defined class of UVs participating in a transitivity alternation with non-causative semantics involves UVs of manner or direction (path) of motion, listed in Tables 9 and 10. These may all occur with both intransitive and transitive IVs of locomotion, as illustrated in (36) for yugung 'run', and in these expressions characterise the manner/direction of motion of either $\mathrm{S}$ or $\mathrm{A}$, respectively.
a. Jayiny ngarrgina yugung ga-ram. MoMo 1SG:POSS run 3SG.S-come.PRS
'My grandchild comes running.'
b. Jalig-di=malang yugung gan-anja=nu (...) child-ERG=GIVEN run 3SG.A>3SG.P-take.PRS=3SG.DAT
'The child takes it (food) for her, running.' (... and gives it to the grandmother)




\section{c. Yugung gan-jib-unga-nyi, (...) \\ run 3SG.A>1SG.P-POT-leave-IMPF}

'He was going to run away from me (but I held him back).'

Table 9. UVs of manner of motion

$\begin{array}{ll}\text { warlnginy, galu(wirrb) } & \text { walk, be on foot, walk around } \\ \text { warrng } & \text { move by moving legs or wings, walk, fly } \\ \text { yugung } & \text { run, race, speed } \\ \text { yawal } & \text { run (of multiple animates) } \\ \text { burdurdub } & \text { race, rush, gallop } \\ \text { dibard } & \text { jump } \\ \text { mingib } & \text { crawl } \\ \text { ngarrang } & \text { stagger } \\ \text { digurrgba } & \text { limp } \\ \text { jaburrb } & \text { wade } \\ \text { liwu, lilaj } & \text { swim } \\ \text { rayib } & \text { sneak } \\ \text { lalama } & \text { rustle }\end{array}$

Table 10. UVs of path and direction of motion

$\begin{array}{ll}\text { burduj } & \text { climb up, move upwards } \\ \text { jid, jag } & \text { move downwards } \\ \text { buru } & \text { return, go back } \\ \text { yirrbag } & \text { move over, shift place } \\ \text { malang } & \text { go across, cross } \\ \text { wurlurlu } & \text { enter (of multiple participants) } \\ \text { jarubaj } & \text { go back and forth } \\ \text { laginy } & \text { take a turnoff } \\ \text { marraj } & \text { go past (point), go through (volume) } \\ \text { walig } & \text { go round, around (in circle- or semi-circle-shaped path) } \\ \text { jurdug } & \text { go in a straight path } \\ \text { buyi } & \text { continue, keep going in same direction }\end{array}$

\subsubsection{Transitivity alternation with UVs of activity $(S=A)$}

A small class of UVs encoding an activity (see also Section 5.4) also participate in a transitivity alternation with non-causative semantics. In this case the transitive alternant invariably expresses the affectedness of a second participant by the activity. Inflecting verbs used in this context tend to be restricted to ganima 'hit' in a secondary sense of 'affect completely', and 
ganingawu 'see' in a secondary sense of 'direct aggression at someone'. The examples in (37) and (38) illustrate the alternation for the UVs ngarlma 'be barking' and gambaja 'be laughing', respectively.
a. Ngarlma=biyang ga-yu.. wirib barking=SEQ 3SG.S-be.PRS dog
'He is barking now, the dog.'
b. Wirib-di ngarlma gani-ngayi-m marlajagu dog-ERG barking 3SG.A>3SG.P-see-PRS goanna

'The dog is barking at the goanna.'
a. Mayi
gambaja ga-yu.
man laugh 3SG.S-be.PRS

'The man is laughing.'
b. Mayi-ni
man laugh
$\begin{array}{ll}\text { gambaja } & \text { gani-ma } \\ \text { laugh } & \text { 3SG.A>3SG.P-hit.PST }\end{array}$
(janyungbari).
another
'The man is laughing at another one.'

\subsubsection{Transitive-ditransitive (locative-recipient) alternation $(L=R)$}

While some trivalent UVs only occur in complex predicates with a ditransitive coding frame (see Section 3.1), a small class of UVs participate in an alternation between a transitive coding frame (with a dative noun phrase encoding a recipient, addressee or beneficiary) and a ditransitive coding frame where this recipient, addressee or beneficiary is promoted to primary object role in terms of indexing on the verb, and is encoded by an absolutive noun phrase (see also Schultze-Berndt 2010). This alternation occurs with UVs semantically selecting for a locative argument, which in the transitive alternant is flagged by one of the spatial cases. In the ditransitive alternant the location is equated with the recipient and is encoded as $\mathrm{R}$ indexed on the verb and absolutive object. Consider the case of lawu 'pour, spill', already illustrated in (31) above. In (39), this UV is combined with the IV of spatial transfer, ganarrany 'put'. In this case, the recipient/beneficiary is expressed by a dative noun phrase and an oblique pronominal clitic; in addition, a spatial goal is specified by a locative-marked NP. The ditransitive alternant is formed with the IV ganingarna 'give'; in this case the R participant is indexed by a verbal prefix rather than an enclitic, and consequently, the overall event is construed as one of transfer of possession, rather than as mere spatial transfer; 
a locationis not specified separately. Apart from lawu 'spill, pour', wurlmaj 'splash with water' also occurs in this alternation.
a. (Nalija)
lawu pour/spill
$n g a-w$-arra $=$ gunyag tea
1SG.A>3SG.P-POT-put=2DU.OBL
birrigud-gi. tin-LOC 'I will pour (tea) for you two, in the tin.'
b. (Nalija) ngabuny-ngarna=biya na: lawu. tea 1SG.A>POT:2DU.P-give=SEQ now pour/spill 'I will pour you two (tea).'

A second example is the alternating use of the syntactically transitive IV ganangu 'get/handle' and the syntactically ditransitive IV ganiyunggany 'rob, take away from' with the UV bunug 'steal', illustrated in (40). The first expression is used when $\mathrm{T}$ (the stolen entity) is not removed from the direct possession of $R$. If $T$ is physically taken away from $R$ (i.e. out of $R^{\prime}$ s hands), the ditransitive alternant is used.

(40) a. chukchuk=biya thanthu bunug gan-angu

chicken=SEQ DEM steal 3SG.A $>3$ SG.P-get/handle.PST
wanang-ngunyi=warra
where-ABL=DOUBT

'She stole that chicken from I don't know where.' (in a film)

b. Majani bunug bun-jungga-ny maybe steal 3DU.A>1SG.P-take.away-PST

'Maybe they robbed me.' (off a bank card, the implication being that it was near the body of the speaker when stolen)

\subsubsection{Ambitransitive alternation $(S=P)$}

In this alternation, the same UV is used both with an intransitive verb and a transitive verb. $S$ in the intransitive version corresponds to $P$ in the transitive version; however, the semantics is not causative/inchoative. This alternation is marginal in terms of the UVs involved. It is illustrated here for ngabuj 'smell'.

(41) a. Ngabuj ga-yu guyug

chicken=SEQ 3SG.S-be.PRS fire

'The fire smells.'

b. Wirib-ni ngabuj ganuny-ngangu dog-ERG smell 3SG.A>3DU.P-get/handle.PST

'The dog smelled the two.' 


\subsubsection{Locative-object (applicative) alternation $(\mathrm{L}=\mathrm{P})$}

This alternation is attested for two UVs, the path UV walig 'move in a circleshaped path, move around', and the positional dibird 'be wound around something', the latter illustrated in (42). Both have in common that they semantically select for a location as well as a theme participant, and that, depending on the situation, the location can simultaneously be conceived of as a patient affected by the encirclement. In the locative alternant, the UVs combine with an intransitive IV, with L flagged by one of the spatial cases. In the "object" alternant, the UV combines with the transitive IVs ganangu 'get/handle' or ganima 'hit' (the latter in a secondary sense of "completely affect", already illustrated in (38)). The operation is similar to an applicative, in that the locative is promoted to direct object status and encoded as P indexed on the verb and as absolutive object; compare the uses of dibird 'be wound around something' with the German near-equivalents sich wickeln (um L) and $P$ umwickeln.

$$
\begin{array}{llll}
\text { a. Dibird } & g a-y u & \text { langiny-gi } & \text { (mununggu) } \\
\text { wound } & \text { 3SG.S-be.PRS } & \text { tree-LOC } & \text { (rope) }
\end{array}
$$

'(A rope) is wound around a tree.' $\begin{array}{lll}\text { b. Dibird } & \text { ngantha-ngga-m } & \text { thanthiya mawud } \\ \text { wound } & \text { 2SG.A>3SG.P-get/handle-PRS DEM glass }\end{array}$

'You wound (something) around that bottle.'

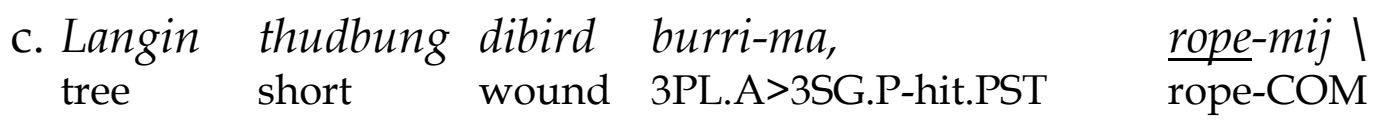

'They wound the short tree with a rope.'

d. dibird=biji=wung yan-iny-mangu garridan-ni wind=only=RESTR IRR-3SG.A>2SG.P-hit yellow.tree.snake-ERG '(It will not bite you,) it will only wind itself around you, the yellow tree snake.'

Interestingly, this alternation does not apply to translation equivalents of many predicates for which one might expect a locative alternation on semantic grounds, e.g. bardag 'be covered', yurr 'rub', and jardi 'be full', for which the "location" is always encoded as a theme. 


\subsection{Telicity alternation}

The telicity alternation has a special status because, unlike the alternations discussed in Section 5.2, it is not only coded by a change of inflecting verb (IV), but also by morphological marking (of iterative lexical aspect) on the uninflecting verb (UV). This makes it more productive and less verb-class specific than any of the other alternations. It is illustrated in (43) to (45).

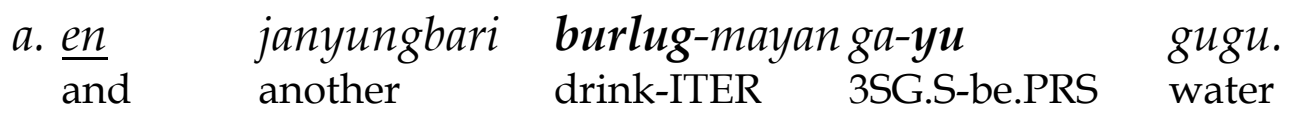

'And the other one is drinking water.'

b. majanigugu burlug gani-bida ngayin-ni thanthu-ni. maybe water drink 3SG.A>3SG.P-POT:eat animal-ERG DEM-ERG 'Maybe it wants to drink water, that animal.'

(44) a. wirib $\boldsymbol{d} \boldsymbol{u}$-mayan ga-yinyji.

dog shoot-ITER 3SG.S-go.IMPF

'He was (going around) shooting dogs.'

b. (Mayi) dirrg-dirrg burrurr-arra-na, person RDP-tied 3PL.A>3PL.P-put-IMPF

burrurr-ijja-na du. 3PL.A>3PL.P-poke-IMPF shoot

'They used to tie them (Aboriginal people) up and shoot them.'

(45) a. langiny=biya dirrg-dirrg-mayan ga-yu=ni nawurlu-ngguluwa tree=SEQ RDP-tied-ITER 3SG.S-be.PRS=SFOC daughter-KIN2

'She is tying up a tree (while building a shed), your daughter.'

$\begin{array}{lll}\text { b. langiny-gi } & \text { dirrg } & g a-y u \\ \text { tree-LOC } & \text { tied } & \text { 3SG.S-be.PRS }\end{array}$

'It is tied up on a tree.' (stative; compare also the causative alternant in (44)b).

As the examples show, one of the alternants involves a telic complex predicate (in the case of (45), the telic counterpart is actually shown in (44)b). In the atelic alternant, the UV is followed by the productive iterative marker -mayan; alternatively, it has one of a number of non-productive endings such as $j a, y a$, or $b$. The IV in the atelic combinations is invariably the intransitive stative/durative verb gagba 'be' or, less frequently, the verb gajgany 'go' which adds a durative or habitual component to the expression. The whole construction is reminiscent of a progressive in some ways, in that they are used in discourse to present an event as ongoing with respect to a reference 
time or, in the case of gajgany ' $g o$ ', as ongoing not relative to a single point in time but relative to a larger time interval (Bertinetto et al. 2000: 523-27).

Moreover, both locative and motion verbs are cross-linguistically common as sources of progressive meaning (Bybee \& Dahl 1989: 79; Bybee et al. 1994: 133). However, the construction behaves just like other complex predicates in all respects, and can be shown to express (iterative) lexical aspect rather than (progressive) grammatical aspect in that it is restricted to events which can be conceived of as either semelfactive or iterative (see Schultze-Berndt forthcoming for details). For example, both burlug 'drink' and $d u$ 'shoot' can be conceived of as single or repeated instances. However, example (45), demonstrates that the alternation is also available to monovalent stative UV like dirrg 'be tied' (which form intransitive stative complex predicates with the same IV gagba 'be'); the combination with the suffix -mayan coerces a dynamic bivalent interpretation, i.e. multiple acts of tying up, corresponding to the transitive telic complex predicate shown in (44)b).

A second special characteristics of this alternation is that it affects the coding frame, but not the numerical valency of the alternants. As the examples also show, the Agent in the (transitive) telic alternant is encoded by an ergative marked NP and the A prefix on the IV, as one would expect; in the atelic alternant the Agent is encoded by the $S$ argument on the IV and as an absolutive noun phrase (in this case, this does not reflect optional ergativity; rather, ergative marking is excluded). The Patient argument is likewise encoded as a second absolutive noun phrase, otherwise impossible with intransitive IVs (see also Section 3.2.3).

\subsection{Predicate classes not participating in alternations}

In addition to the UVs discussed in the previous subsections, there exist a large number of UVs which do not participate in valency alternations except (possibly) for the telicity alternation which is also encoded on the UV. However, they will often combine with more than one IV encoding specific features of the event. Three major classes of UVs not participating in valency alternations are discussed below.

The first class is composed of monovalent UVs expressing internally caused events including events of sound emisson, speech act, internal motion, and bodily or emotional condition; a representative list is provided in Table 11. These all combine with the polyfunctional IV ganiyu 'say, do' in its syntactically intransitive reading (see Section 3.2.2, and also Section 5.2.4 for some exceptions). A typical example is winy 'whistle', illustrated in (46) 
winy nganth-unggu-m,

whistle 2SG.A>3SG.P-say/do-PRS

nganthan jalag nanthi-ngawu?

what good 2SG.A>3SG.P-see.PST

'you are whistling, what kind of good thing have you found?'

Table 11. UVs expressing internally caused events

$\begin{array}{ll}\text { bawa } & \text { call out, shout } \\ \text { winy } & \text { whistle } \\ \text { ngujul } & \text { cough } \\ \text { ngajirr } & \text { sneeze } \\ \text { daggarrag } & \text { burp, hiccough } \\ \text { dirrng } & \text { fart } \\ \text { yirrirrib } & \text { rustle, make a noise } \\ \text { jilag } & \text { report, tell an experience } \\ \text { jaj } & \text { say/warn in vain } \\ \text { gumbulung } & \text { tell the truth } \\ \text { mirrung } & \text { tell a lie, deceive, pretend } \\ \text { dalala } & \text { shiver, shake } \\ \text { burrurrd } & \text { shake in fright, shudder } \\ \text { duwaj, nunaj } & \text { nod (with the head) } \\ \text { mangan } & \text { wave } \\ \text { mangmang } & \text { move knees in and out (in women's dance) } \\ \text { yimij } & \text { blink (with the eye) } \\ \text { wuburr } & \text { be turbulent (of water) } \\ \text { burrngburrng } & \text { bubble, boil up } \\ \text { nyam } & \text { float up (of fish after being poisoned) } \\ \text { yarl } & \text { be itchy } \\ \text { jalug } & \text { be lively, excited }\end{array}$

A second large class of UVs not undergoing alternations are UVs of continuous activity, with members from a variety of semantic fields. This class does not exhaust the class of activity predicates, in Vendler's sense of 'activity', which includes, for example, also UVs of manner of motion. Rather, the class of UVs of continuous activity is defined formally in that its members combine almost exclusively with the IVs gayu 'be' and gajgany 'go' which with these UVs function as mere markers of atelicity. This class includes conventionalised activities consisting of multiple sub-events such as thawaya 'eating', wajama 'fishing' and wirrigaja 'cooking'; as (47) shows, these may be bivalent and allow two absolutive noun phrases (see Section 3.2.3). A few alternating members of the class are discussed in Section 5.2.8. 


$\begin{array}{lllll}\text { Guruwuny } & \text { thawaya } & \text { ga-yu } & \text { jalig } & \text { wuju. } \\ \text { boab } & \text { eat } & \text { 3SG.S-be.PRS } & \text { child } & \text { small }\end{array}$

'The small child is eating boab nuts.'

The final type of UVs which does not allow a change of UV bringing about a valency change consists of bivalent UVs with a manner component, e.g. manner of touch, manipulation, or impact. Some frequent UVs of this type are listed in Table 12. Notably, UVs like wunyu 'wipe out', wirrb 'wipe' and yurr 'rub' only occur in a pattern where the ground affected by the wiping, not the substance wiped, is encoded as P (direct object). The lexical aspectual distinction between activity and accomplishment can still be expressed by the choice of the IVs ganangu 'get/handle' and ganima 'hit; completely affect', respectively, as illustrated in (48).
a. gidbi-ni
yurr nga-bili
guruwuny red.ochre-ERG/INST rub 1SG.A>3SG.P-POT:get/handle boab 'I'm going to rub the boab nut with red ochre.'
b. yurr nga-ba-ji yathang, mangurrbbari-ni rub 1SG.A-POT:hit-REFL allright black-ERG/INST 'I will die my hair all right, with black die.' (lit. 'I will rub myself, with black')

Table 12. Bivalent UVs with a manner component not undergoing valency alternations

$\begin{array}{ll}\begin{array}{ll}\text { mard } \\ \text { lurrb }\end{array} & \text { touch } \\ \text { durd } & \text { seize, grab } \\ \text { garrb } & \text { hold or pick up a single entity } \\ \text { laburru } & \text { hold or pick up multiple entities or mass; gather } \\ \text { nyittiny } & \text { scoop up water } \\ \text { buny } & \text { pinch } \\ \text { ngalyag } & \text { kiss } \\ \text { gulyu } & \text { lick } \\ \text { warr } & \text { wash, rinse } \\ \text { wunyu } & \text { scratch } \\ \text { yurr } & \text { wipe (out) } \\ \text { wij } & \text { rub } \\ \text { gurr } & \text { scrape } \\ \text { ngarrg } & \text { dig } \\ \text { durl } & \text { strangle } \\ \text { wanywany } & \text { push } \\ \text { beat, belt }\end{array}$




$\begin{array}{ll}\text { burrg } & \text { hit with hands, clap } \\ \text { durrg } & \text { sweep } \\ \text { jang } & \text { chew }\end{array}$

\section{Discussion/conclusion}

The existence of two distinct "verbal" parts of speech has far-reaching consequences for the grammatical manifestations of valency in Jaminjung (and in a comparable fashion in other languages in a linguistic area in Northern Australia with a similar part of speech division). As already pointed out at the beginning of Section 3 above, it also raises the question of what should be considered as "verbs" for the purposes of investigating valency and verb classes. Translation equivalents of the meaning labels forming the basis for this investigation, for example, can be simple IVs (semantically generic inflecting verbs from a closed class, e.g. gardbany 'fall') or complex predicates (e.g. waga gardbany 'sit down'), or in fact nominal predicates or $\mathrm{N}+\mathrm{V}$ collocations, e.g. gugu gardbany 'water + fall' = 'rain', not further discussed in this paper. Predicate classes based on coding frames can be established only for IVs and complex predicates, as shown in Section 4. However, as shown in Section 5, the main strategy of achieving valency change - in the absence of derivational mechanisms - is a change of IV in complex predicates, with an accompanying change in coding frame, while leaving the UV (uninflecting, open class predicative part of speech) constant. As a result, predicate classes based on alternations (or absence of alternations) can be established mainly for UVs. Indeed, the classes of UVs established by this diagnostics partly correspond to predicate classes attested cross-linguistically. Examples discussed here are predicates of externally caused change of state, participating in a causative-inchoative alternation (Section 5.2.1), predicates of internal causation (rarely alternating; see Section 5.4), predicates of manner of motion (exhibiting an $\mathrm{S}=\mathrm{A}$ alternation, see Section 5.2.7), predicates of posture / position (participating in a causative-inchoative-stative alternation; see Section 5.2.5), and predicates of manner of manipulation or impact (nonalternating except possibly for the telicity alternation; see Section 5.4). In addition, the same method also revealed predicate classes corresponding to rather language-specific (possibly culture-specific) lexical fields, such as that of manner of application of heat (participating in a causative-inchoative pattern, see Section 5.2.3) or direction of gaze (participating in an $S=A$ alternation, see Section 5.2.6). 
The particular partition of the verbal lexicon in Jaminjung into an open class of UVs and a closed class of IVs also brings about a particular division of labour between the two classes, which in turn leads to a skewed distribution of the major valency classes between the two parts of speech: Overall, there are many more monovalent than bivalent or trivalent UVs, owed to the existence of large classes of UVs of position/configuration, externally caused change of state, change of location, manner of motion, and internal causation, which are all monovalent. Conversely, there are many more transitive (20+) than intransitive (5) or ditransitive (2) IVs. In complex predicates, while the valency of UV and IV can of course also be identical, it is often the IV that contributes an additional $\mathrm{A}$ (in causative combinations) or P argument. This can be seen as a manifestation of Economy, since it greatly increases the combinatorial potential of UVs, which after all are the open class of predicates in the language. Thus, caution needs to be exerted when determining a position on a "transitivity hierarchy" for Jaminjung since the position will be radically different depending on whether UVs, IVs, or complex predicates are taken as "verb" equivalents.

\section{References}

Baker, Brett \& Mark Harvey. 2010. Complex predicate formation. In M. Amberber, B. Baker \& M. Harvey (eds), Complex predicates. Cross-linguistic perspectives on event structure, 13-47. Cambridge: Cambridge University Press.

Bertinetto, Pier Marco, Karen H. Ebert \& Casper de Groot. 2000. The progressive in Europe. In Ö. Dahl (ed.) Tense and Aspect in the Languages of Europe, 517-58. Berlin: Mouton de Gruyter.

Butt, Miriam. 1997. Complex predicates in Urdu. In A. Alsina, J. Bresnan \& P. Sells (eds), Complex Predicates, 107-49. Stanford CA: CSLI Publications.

Bybee, Joan L. \& Östen Dahl. 1989. The creation of tense and aspect systems in the languages of the world. Studies in Language 13: 51-103.

Bybee, Joan, Revere Perkins \& William Pagliuca. 1994. The Evolution of Grammar: Tense, Aspect and Modality in the Languages of the World Chicago: Chicago University Press.

Capell, Arthur. 1979. Classification of verbs in Australian languages. In S.A. Wurm (ed.) Australian Linguistic Studies, 229-322. Canberra: Pacific Linguistics.

Chadwick, Neil. 1997. The Barkly and Jaminjung languages: a non-contiguous genetic grouping. In T. Darrell T. \& M. Walsh (eds), Boundary rider: STudies in the lexicology and comparative linguistics of Australian languages. Canberra: Pacific Linguistics.

DeLancey, Scott. 1991. Event Construal and case role assignment. Berkeley Linguistic Society 17: 338-53.

Dixon, R. M. W. 2001. The Australian linguistic area. In A.Y. Aikhenvald \& R.M.W. Dixon (eds), Areal Diffusion and Genetic inheritance. Problems in comparative linguistics, 64-104. Oxford: Oxford University Press.

Dowty, D.R. 1991. Thematic proto-roles and argument selection. Language 67: 547-619.

Dryer, Matthew S. 1986. Primary objects, secondary objects, and antidative. Language 62: 808-45.

Foley, William A. \& Robert D. Van Valin. 1984. Functional syntax and universal grammar Cambridge: Cambridge University Press. 
Gaby, Alice. 2008. Rebuilding Australia's linguistic profile: Recent developments in research on Australian aboriginal languages. Language and Linguistics Compass 2: 211-33.

Harvey, Mark. 2008. Proto Mirndi. A discontinuous language family in northern Australia. Canberra: Pacific Linguistics.

Haspelmath, Martin. 2005. Argument marking in ditransitive alignment types. Linguistic Discovery 3: 1-21.

Levin, Beth \& Malka Rappaport Hovav. 1995. Unaccusativity at the syntax-lexical semantics interface Cambridge, MA: MIT Press.

Malchukov, Andrej, Martin Haspelmath \& Bernard Comrie. 2010. Ditransitive constructions: a typological overview. In A. Malchukov, M. Haspelmath \& B. Comrie (eds), Ditransitive constructions: a comparative Handbook. Berlin: Mouton de Gruyter.

McGregor, William B. 1992. The semantics of ergative marking in Gooniyandi. Linguistics 30: 275-318.

-. 1998. Optional ergative marking in Gooniyandi revisited: implications for the theory of marking. Leuvense Bijdragen 87: 491-534.

- 2002. Verb classification in Australian languages Berlin: Mouton de Gruyter.

-. 2006. Focal and optional ergative marking in Warrwa (Kimberley, Western Australia). Lingua 116: 393-423.

-. 2010. Optional ergative case marking systems in a typological-semiotic perspective. Lingua 120: 1610-36.

Nichols, Johanna. 1986. Head-marking and dependent-marking grammar. Language 62: 56119.

Schultze-Berndt, Eva. 2000. Simple and complex verbs in Jaminjung: A study of event categorisation in an Australian language. Nijmegen: University of Nijmegen.

-. 2003. Preverbs as an open word class in Northern Australian languages: synchronic and diachronic correlates. In G. Booij \& J.v. Marle (eds), Yearbook of Morphology 2003, 145-77. Dordrecht: Kluwer.

-. 2006. Towards a semanto-pragmatic account of optional ergativity in Jaminjung/Ngaliwurru. Paper presented at the Second European Workshop on Australian Languages, 23rd-25th April 2006, Somlószöllös, Hungary.

- 2010. Grammatical properties and classification of three-participant predicates in Jaminjung. In A. Malchukov, M. Haspelmath \& B. Comrie (eds), Studies in Ditransitive Constructions, 510-28. Berlin: Mouton de Gruyter.

Schultze-Berndt, Eva \& Candide Simard. to appear. Constraints on noun phrase discontinuity in an Australian language: the role of prosody and information structure. Linguistics.

Silverstein, Michael. 1986. Classifiers, verb classifiers, and verbal categories. BLS 12: 497514.

Tsunoda, Tasaku. 1981. Split case-marking patterns. Linguistics 19: 389-438.

Van Valin, Robert D. \& Randy J. LaPolla. 1997. Syntax: Structure, meaning and function Cambridge: Cambridge University Press.

Van Valin, Robert D. \& David Wilkins. 1996. The case for 'effector': case roles, agents, and agency revisited. In M. Shibatani \& S.A. Thomas (eds), Grammatical constructions: their form and meaning, 289-322. Oxford: Clarendon Press. 